\title{
Effect of Methyltrienolone on the Metabolic Disorders in Rat Model of Alloxan-Induced Diabetes
}

\author{
Neli Didebulidze MBiol, PhD \\ Ivane Javakhishvili Tbilisi State University (TSU), Tbilisi, Georgia \\ Alexandre Natishvili Institute of Morphology, TSU, Tbilisi, Georgia \\ Sopiko Kandelaki MD \\ Ivane Javakhishvili Tbilisi State University (TSU), Tbilisi, Georgia

\section{Manana Kakabadze MD, PhD} \\ Ivane Javakhishvili Tbilisi State University (TSU), Tbilisi, Georgia \\ Alexandre Natishvili Institute of Morphology, TSU, Tbilisi, Georgia
}

\section{Salome Kordzaia BM}

David Tvildiani Medical University, Tbilisi, Georgia

\section{Dimitri Kordzaia MD, PhD}

Ivane Javakhishvili Tbilisi State University (TSU), Tbilisi, Georgia Alexandre Natishvili Institute of Morphology, TSU, Tbilisi, Georgia

\section{Jordi Muntané Relat MD, PhD}

Department of General Surgery, University Hospital Virgen del

Rocio/IBiS/CSIC/University of Seville, Seville, Spain Centro de Investigación Biomédica en Red de Enfermedades Hepáticas y

Digestivas (CIBERehd), Spain

\section{Javier Padillo MD, PhD}

Department of General Surgery, University Hospital Virgen del

Rocio/IBiS/CSIC/University of Seville, Seville, Spain

de Investigación Biomédica en Red de Enfermedades Hepáticas y Digestivas

(CIBERehd), Spain

\section{doi: 10.19044/esj.2017.v13n15p22 $\quad$ URL:http://dx.doi.org/10.19044/esj.2017.v13n15p22}

\begin{abstract}
Aim: The aim of the study was to investigate the restoration of metabolic imbalance related with deficiency of insulin by the exogenous androgen supplementation in the experimental model of alloxan-induced diabetes in Wistar male rats. Methods: The experimental diabetes was induced by a single intraperitoneal administration of alloxan. The concentrations of glucose, immunereactive insulin, corticosterone, testosterone and estradiol were examined in blood, the intensity of DNA and RNA synthesis and androgen receptor expression were studied in the liver
\end{abstract}


tissue - at $15^{\text {th }}, 30^{\text {th }}$ and $45^{\text {th }}$ days of alloxan-induced diabetes. The synthetic androgen methyltrienolone was administered to rats with 30-days diabetes during 15 days. All data were compared to control group received solvent. Results: The induction of diabetes increased the concentrations of glucose, corticosterone and estradiol while decreases insulin and testosterone concentration in blood as well as DNA/RNA synthesis and androgen receptors expression in hepatocytes. The administration of exogenous androgen significantly restored the metabolic imbalance and the expression of androgen receptors and increased DNA/RNA synthesis in liver cells maintained close to control level. Conclusion: The administration of methyltrienolone reduced the effect of "diabetic stress" and restored the hormonal dysfunction induced by alloxan.

Keywords: Alloxan-induced diabetes, testosterone, liver androgen receptors, hormonal disbalance

\section{Introduction}

According to World Health Organization data, the incidence of diabetes mellitus (DM) has been obviously increasing over the world during the last decades. Both types of DM (type 1 and type 2) are characterized by chronic hyperglycemia and disorders in metabolism of carbohydrates, proteins and fats (American Diabetes Association, 2009), with multi-organ involvement in the pathogenesis (Hotamisligil, 2006).

The gender difference in the population affected by DM has been demonstrated by numerous epidemiological studies (Fitzgerald, et al., 1995; Grant, et al, 2009; Siddiqui, et al., 2013). It is considered that males have higher prevalence and diabetes type 2 risk (Aregbesola ET AL., 2016; Kautzky-Willer, et al., 2016). In addition, the risk of men with type 1diabetes by cardiovascular disease mortality is approximately 10 times that of men without diabetes (Orchard, et al., 1990). Moreover the diabetes is considered as one of the strongest independent predictors of left ventricular hypertrophy (Greaves, et al., 1994).

Sex hormones have a great impact on energy metabolism, body composition, vascular function, and inflammatory responses (KautzkyWiller, et al., 2016). The credible decrease of plasma testosterone concentration has been shown in males affected by DM type 1 as well as type 2. It was shown that the low concentrations of endogenous testosterone correlates with increased risk for left ventricular hypertrophy and heart failure (Kannel, et al., 1969; Kannel, et al., 1972). It is also reported that the reduction of blood testosterone concentration leads to the changes of metabolic processes in liver, hyperglycemia and insulin resistance in men with both types of DM (Grossmann, 2008; Holt, 2014). The low level of 
blood testosterone is related to worst outcome in advanced liver diseases (Sinclair, 2016). The influence of sex hormones on the insulin secretion by $\beta$-cells in pancreas and metabolic processes in liver has been proved (Morimoto, 2001; Shen \& Shi, 2015).

Considering, that hepatocytes and $\beta$-cells have the receptors for both male and female sex hormones, which in turn, have the ability of changing their quantitative expression ("down-regulation" and "up-regulation") accordingly to their blood concentration, it could be expected that sex hormones supplementation may have functional pancreatic and hepatic repercussions in DM.

At the same time it's shown that male's liver, compared to female's, is more dependent on the genetically determined androgen levels in blood (Smirnov, 2009).

The aim of the present study was to investigate the possibility of restoration of metabolic imbalance by the exogenous androgen supplementation in the experimental model of alloxan-induced diabetes (AD).

\section{Material And Methods}

The experimental model of diabetes was induced in male Wistar white rats $(n=80)$ in age 2-2,5 months, weighting 180-200 g by a single intraperitoneal administration of alloxan obtained from Chemos $\mathrm{GmbH} \&$ Co.KG (Germany). The animals received alloxan $200 \mathrm{mg} / \mathrm{kg}$ body weight in accordance to the pattern of experimental group. The animals were divided into 5 groups: Group I (Control) $(n=20)$ received solvent; Group II $(n=20)$ studied on $15^{\text {th }}$ day of AD; Group III $(n=20)$ studied on $30^{\text {th }}$ day of AD; Group IV $(n=20)$ studied on $45^{\text {th }}$ day of AD; Group V $(n=20)$ received daily $0.5 \mathrm{mg}$ of synthetic androgen - radioinert methyltrienolone - beginning from the $31^{\text {st }}$ day of AD. One hour before sacrifice, all animals underwent to the intraperitoneal injection of $3,7 \times 10^{4} \mathrm{~Bq}$ radioactive androgen methyltrienolone [17a-METHYL-3H] (R-1881) obtained from Perkin Elmer, Inc., for quantitative assessment of androgen receptors (AR) in liver.

Subsequently, the animals were given ether anesthesia and the blood samples were obtained from inferior vena cava to further measuring the levels of glucose, immunoreactive insulin (IRI), corticosterone, estradiol ( $\left.\mathrm{E}_{2}\right)$ and testosterone (T). The study corresponded to the principles of the Guide for the Care and Use of Laboratory Animals (NRC 2011) and approved by the Commission on Bioethics at Al. Natishvili Institute of Morphology, Iv. Javakhishvili Tbilisi State University. 


\section{Measurement of hormones}

The levels of hormones were measured by commercial kits. IRI was determined using the assay from SEA-IRE-SORIN (France); corticosterone was assessed using the assay from RSL., Inc. (California, US), T - by SORIN BIOMEDICA (Italy) and $\mathrm{E}_{2}$ - by ORIS Industries S.A. International GIS (France).

\section{Measurement of hepatic DNA/RNA content}

The quantity of DNA in liver was studied by radioactive $\mathrm{H}^{3}$ thymidine (I.U. $8.14 \times 10^{11} \mathrm{~Bq} / \mathrm{ml}$ ) in the dose of $3.7 \times 10^{5} \mathrm{~Bq} / \mathrm{ml}$, while the RNA was measured by radioactive $\mathrm{H}^{3}$-uridine (I.U. $8.8 \times 10^{11} \mathrm{~Bq} / \mathrm{ml}$ ) in the dose of $3.7 \times 10^{6} \mathrm{~Bq} / \mathrm{ml}$. For this purpose, the fragments of liver tissue were weighed and placed into $5 \mathrm{ml} 199$ solution vials, to which the above specific radioactive components were added.

The vials were placed in thermostat at $+38^{\circ} \mathrm{C}$ for 90 minutes. Later, the fragments were rinsed in cold $\left(+4^{\circ} \mathrm{C}\right)$ nourishing buffer with subsequent homogenization and placement in scintillating fluid container vials (according to previously published recommendations (Didebulidze, et al., 2015. The frequency (quantity) of radioactive impulses (imp/gr/min) was calculated by the " $\beta-2$ " device (produced by the Enterprise of Academy of Medical Sciences, Russia).

\section{Statistical analysis}

Median values are provided with respective interquartile ranges. Comparisons were tested using Mann-Whitney $\mathrm{U}$ test. $\mathrm{P}$ values less than 0.05 were considered statistically significant. Statistical analysis was conducted using SAS 9.2 software.

We preferred median over mean because of concerns regarding the normality of distribution and small sample size of our study. Therefore we thought that median values are more appropriate to describe our data and make comparison between groups, which consisted of 20 subjects each.

\section{Results and Discussion}

AD was accompanied by the increased plasma concentration of glucose, corticosterone and $\mathrm{E}_{2}$. This increase appeared to be statistically significant compared with data of control group and groups with lesser terms of $\mathrm{AD}$ as well. The plasma concentration of IRI and $\mathrm{T}$ has significantly decreased at $15^{\text {th }}$ and $30^{\text {th }}$ days of the experiment but on the $45^{\text {th }}$ day their further changes compared with previous terms were not statistically significant (Table 1, Diagram 1).

This could be related to the reduction of damaging effect of alloxan at $45^{\text {th }}$ day when pancreatic $\beta$-cells entered into regeneration phase. The 
reduction of intensity of IRI decline is accompanied by the reduction of intensity of $\mathrm{T}$ decline as well as it was described by Kandeel, et al. (2007). It is established that hypoinsulinemia and decreased glucose utilization inhibit protein, DNA and RNA synthesis in hepatocytes. In our study, hepatic DNA synthesis was decreased by $44 \%$ and RNA synthesis by $29 \%$ at $15^{\text {th }}$ day of AD. In case of hypoinsulinemia and hyperglycemia, the glucose, which abundantly penetrated into hepatocytes (insulin is not required for the entrance of glucose in the hepatocytes, but only for its utilization by the cells - Kelly \& Jones, 2013) promotes a significant increase in the production of hydroxyl radicals, which increase the amount of Bcl-2-associated $\mathrm{X}$ protein (BAX-protein). Besides, BAX protein stimulates the release of cytochrome $\mathrm{C}$ from mitochondria, caspase-3 activation and induction of apoptosis (Frances, et al., 2010).

After injection of radio-inert methyltrienolone, the glucose level significantly decreased being not statistically different in comparison with the data obtained at $15^{\text {th }}$ day of experiment. This can be explained by the fact, that testosterone promotes the synthesis of i-RNA of IRI receptors in hepatocytes, which leads to increased sensitivity of hepatocytes toward IRI. In this conditions the minimal rise of IRI is enough to stimulate the glucose utilization in liver cells (Kapoor, et al., 2006; Sato, et al., 2008). IRI exerts anti-apoptotic properties based on the stimulation of XIAP, which inhibits caspases and suppresses the apoptosis (Frances, et al., 2010).

Our study, supports that injection of exogenous androgen supplementation significantly increases DNA (24\%) and RNA (8\%) synthesis in liver (Diagram 2).

$\mathrm{T}$ shifts insulin signaling toward cellular protein anabolism (Shahidi, 2001). T increases Glut4 expression and downstream signaling such as Akt and PKC-zeta/lambda phosphorylations and the main glycolytic phosphofructokinase and hexokinase enzymes (Sato, et al., 2008). Injection of methyltrienolone, had no effect on the concentration of IRI: the latter was not different neither from the data obtained at $30^{\text {th }}$ nor $45^{\text {th }}$ days of $A D$ model.

Due to reduction of rat $\beta$-cells-derived insulin by alloxan imply, the synthesis of $\mathrm{T}$ is not stimulated adequately. Reduced $\mathrm{T}$ concentration can no longer afford inhibition of lipoprotein lipase enzyme. This enzyme, located at the endothelial membranes of blood capillaries into adipose tissue, releases the triglycerides from fat rich chylomicrons and very low density lipoproteins; these triglycerides penetrate and deposit into adipocytes. Under these conditions the enzyme aromatase, located in adipocytes, is activated and converts already diminished $\mathrm{T}$ to estrogen. This observation is confirmed by our data in which the marked increase in $\mathrm{E}_{2}$ concentration paralleled the decrease in the $\mathrm{T}$ concentration (Hayes, et al., 2000, 2001). However, the $\mathrm{E}_{2}$ 
concentration which was increased at all stages of the experiment still declined after methyltrienolone injection and was not statistically different from indices of $15^{\text {th }}$ day of $\mathrm{AD}$ (Table 1, Diagram 1).

The presented data confirms the results of Shahidi (2001), Haffner, et al. (1988) and Pitteloud, et al. (2005) that the variability in the steroid hormone concentration is dependent on insulin and glucose levels and vice versa.

At the $15^{\text {th }}$ day of $\mathrm{AD}$ it was observed an increase of liver $\mathrm{AR}$ expression (Diagram 2). This can be explained by active consumption of testosterone during alloxan-dependent stress that increased the number of free AR enabled to interact with radioactive androgen $\mathrm{H}^{3}$-methyltrionolone (R-1881). At subsequent stages the increased testosterone deficiency induced by experimental diabetes was associated with drastic down-regulation of AR expression and signaling (due to their "masking") (Tepperman, 1968; Moudgil, 1988,1990). 
Table 1. Blood concentration of glucose, IRI, T, $\mathrm{E}_{2}$, corticosterone (Cor); activity of nucleic acids (DNA and RNA) synthesis; expression of AR.

\begin{tabular}{|c|c|c|c|c|c|c|c|c|c|}
\hline \multirow[b]{2}{*}{ 童 } & I & \multicolumn{2}{|c|}{ II. } & \multicolumn{2}{|c|}{ III. } & \multicolumn{2}{|c|}{ IV. } & \multicolumn{2}{|c|}{ V. } \\
\hline & $\begin{array}{l}\text { Control } \\
(\mathbf{n}=\mathbf{2 0})\end{array}$ & $\begin{array}{l}\text { Diabetes - } \\
15 \quad \text { days } \\
(\mathrm{n}=20)\end{array}$ & p value & $\begin{array}{l}\text { Diabetes - } 30 \\
\text { days }(n=20)\end{array}$ & p value & $\begin{array}{l}\text { Diabetes - } 45 \\
\text { days }(n=20)\end{array}$ & p value & $\begin{array}{l}\text { Diabetes }-45 \\
\text { days (15 days } \\
\text { getting } \\
\text { methyltrienolo } \\
\text { ne) }(n=20)\end{array}$ & p value \\
\hline $\begin{array}{l}\text { 岁 } \overline{0} \\
\text { 总 }\end{array}$ & $\begin{array}{l}5.10 \\
(4.90- \\
5.20)\end{array}$ & $\begin{array}{l}12.30 \\
(10.80- \\
12.85)\end{array}$ & $<0.0001^{*}$ & $\begin{array}{l}13.35 \\
(12.90-13.60)\end{array}$ & $\begin{array}{l}<0.0001^{*} \\
<0.0004^{* *}\end{array}$ & $\begin{array}{l}15.00 \\
(14.55-15.60)\end{array}$ & $\begin{array}{l}<0.0001^{*} \\
<0.0001^{* *} \\
<0.0001^{* * *}\end{array}$ & $\begin{array}{l}11.35 \\
(10.54-12.11)\end{array}$ & $\begin{array}{l}<0.0001^{*} \\
0.08^{* *} \\
<0.0001^{* * *} \\
<0.0001^{* * * * *}\end{array}$ \\
\hline 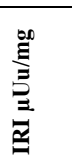 & $\begin{array}{l}23.30 \\
(22.35- \\
24.10)\end{array}$ & $\begin{array}{l}12.42 \\
(11.89- \\
13.06)\end{array}$ & $<0.0001^{*}$ & $\begin{array}{l}5.00 \\
(4.70-5.40)\end{array}$ & $\begin{array}{l}<0.0001 * \\
<0.0001 * *\end{array}$ & $\begin{array}{l}4.72 \\
(4.63-4.88)\end{array}$ & $\begin{array}{l}<0.0001^{*} \\
<0.0001^{* *} \\
0.05^{* * *}\end{array}$ & $\begin{array}{l}4.90 \\
(4.59-5.05)\end{array}$ & $\begin{array}{l}<0.0001^{*} \\
<0.0001 * * \\
0.14 * * * \\
0.32 * * * *\end{array}$ \\
\hline $\begin{array}{l}\underset{B}{E 0} \\
\Xi \\
E\end{array}$ & $\begin{array}{l}2.63 \\
(2.59- \\
2.69)\end{array}$ & $\begin{array}{l}1.73 \\
(1.68-1.80)\end{array}$ & $<0.0001^{*}$ & $\begin{array}{l}1.38 \\
(1.34-1.44)\end{array}$ & $\begin{array}{l}<0.0001^{*} \\
<0.0001 * *\end{array}$ & $\begin{array}{l}1.38 \\
(1.31-1.41)\end{array}$ & $\begin{array}{l}<0.0001^{*} \\
<0.0001^{* *} \\
0.61 * * *\end{array}$ & $\begin{array}{l}2.40 \\
(2.34-2.47)\end{array}$ & $\begin{array}{l}<0.0001^{*} \\
<0.0001^{* *} \\
<0.0001^{* * *} \\
<0.0001^{* * * *}\end{array}$ \\
\hline 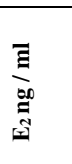 & $\begin{array}{l}0.015 \\
(0.013- \\
0.016)\end{array}$ & $\begin{array}{l}0.019 \\
(0.017- \\
0.020)\end{array}$ & $<0.0001^{*}$ & $\begin{array}{l}0.023 \\
(0.021-0.025)\end{array}$ & $\begin{array}{l}<0.0001 * \\
<0.0001 * *\end{array}$ & $\begin{array}{l}0.032 \\
(0.031-0.034)\end{array}$ & $\begin{array}{l}<0.0001^{*} \\
<0.0001^{* *} \\
<0.0001^{* * *}\end{array}$ & $\begin{array}{l}0.019 \\
(0.017-0.021)\end{array}$ & $\begin{array}{l}<0.0001^{*} \\
0.18^{* *} \\
0.0001^{* * *} \\
<0.0001^{* * * * *}\end{array}$ \\
\hline$\ddot{\bar{\theta}} \frac{\bar{g}}{g 0}$ & $\begin{array}{l}12.83 \\
(11.72- \\
13.45)\end{array}$ & $\begin{array}{l}18.58 \\
(17.90- \\
19.03)\end{array}$ & $<0.0001^{*}$ & $\begin{array}{l}22.15 \\
(21.24-22.53)\end{array}$ & $\begin{array}{l}<0.0001 * \\
<0.0001 * *\end{array}$ & $\begin{array}{l}23.90 \\
(22.05-24.85)\end{array}$ & $\begin{array}{l}<0.0001^{*} \\
<0.0001^{* *} \\
0.005^{* * *}\end{array}$ & $\begin{array}{l}20.45 \\
(19.60-20.95)\end{array}$ & $\begin{array}{l}<0.0001^{*} \\
<0.0001^{* *} \\
<0.0001^{* * *} \\
<0.0001^{* * * *}\end{array}$ \\
\hline 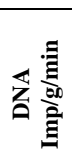 & $\begin{array}{l}180846 \\
(180816 \\
- \\
180872)\end{array}$ & $\begin{array}{l}101276 \\
(101272- \\
101283)\end{array}$ & $<0.0001^{*}$ & $\begin{array}{l}121163 \\
(121157- \\
121170)\end{array}$ & $\begin{array}{l}<0.0001 * \\
<0.0001 * *\end{array}$ & $\begin{array}{l}106698 \\
(106683- \\
106711)\end{array}$ & $\begin{array}{l}<0.0001^{*} \\
<0.0001^{* *} \\
<0.0001^{* * *}\end{array}$ & $\begin{array}{l}150096 \\
(150086- \\
150106)\end{array}$ & $\begin{array}{l}<0.0001^{*} \\
<0.0001^{* *} \\
<0.0001^{* * *} \\
<0.0001^{* * * * *}\end{array}$ \\
\hline 売畐 & $\begin{array}{l}324909 \\
(324870 \\
- \\
324963)\end{array}$ & $\begin{array}{l}230701 \\
(230671- \\
230712)\end{array}$ & $<0.0001^{*}$ & $\begin{array}{l}259956 \\
(259949- \\
259962)\end{array}$ & $\begin{array}{l}<0.0001 * \\
<0.0001 * *\end{array}$ & $\begin{array}{l}243700 \\
(243687- \\
243714)\end{array}$ & $\begin{array}{l}<0.0001^{*} \\
<0.0001^{* *} \\
<0.0001^{* * *}\end{array}$ & $\begin{array}{l}282696 \\
(282683- \\
282707)\end{array}$ & $\begin{array}{l}<0.0001^{*} \\
<0.0001^{* *} \\
<0.0001^{* * *} \\
<0.0001^{* * * * *}\end{array}$ \\
\hline 芲高 & $\begin{array}{l}1673.17 \\
(1636.69 \\
- \\
1705.25)\end{array}$ & $\begin{array}{l}1885.95 \\
(1876.15- \\
1894.55)\end{array}$ & $<0.0001^{*}$ & $\begin{array}{l}1121.86 \\
(1109.23- \\
1135.32)\end{array}$ & $\begin{array}{l}<0.0001 * \\
<0.0001 * *\end{array}$ & $\begin{array}{l}1003.43 \\
(997.68- \\
1013.45)\end{array}$ & $\begin{array}{l}<0.0001^{*} \\
<0.0001^{* *} \\
<0.0001^{* * *}\end{array}$ & $\begin{array}{l}1509.53 \\
(1498.20- \\
1516.34)\end{array}$ & $\begin{array}{l}<0.0001^{*} \\
<0.0001^{* *} \\
<0.0001^{* * *} \\
<0.0001^{* * * * *}\end{array}$ \\
\hline
\end{tabular}

Number of $(*)$ indicates the group which data is compared to the data of given group 
Diagram 1. Concentrations (in percents) of glucose, IRI, corticosterone, $\mathrm{E}_{2}$ and $\mathrm{T}$ in blood of male rats.

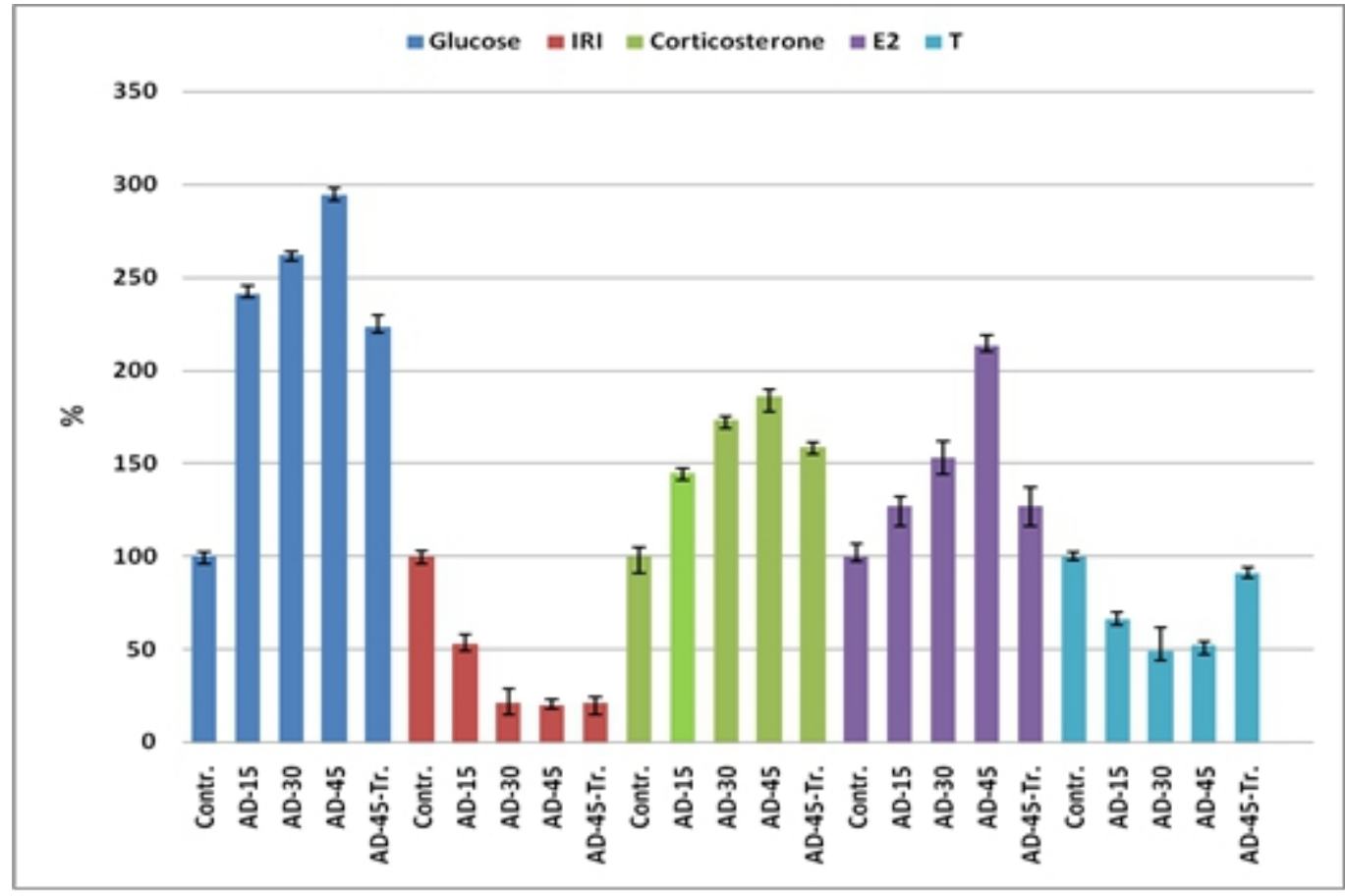

Diagram 2. Levels of DNA and RNA synthesis and AR expression in the liver tissue of male rats.

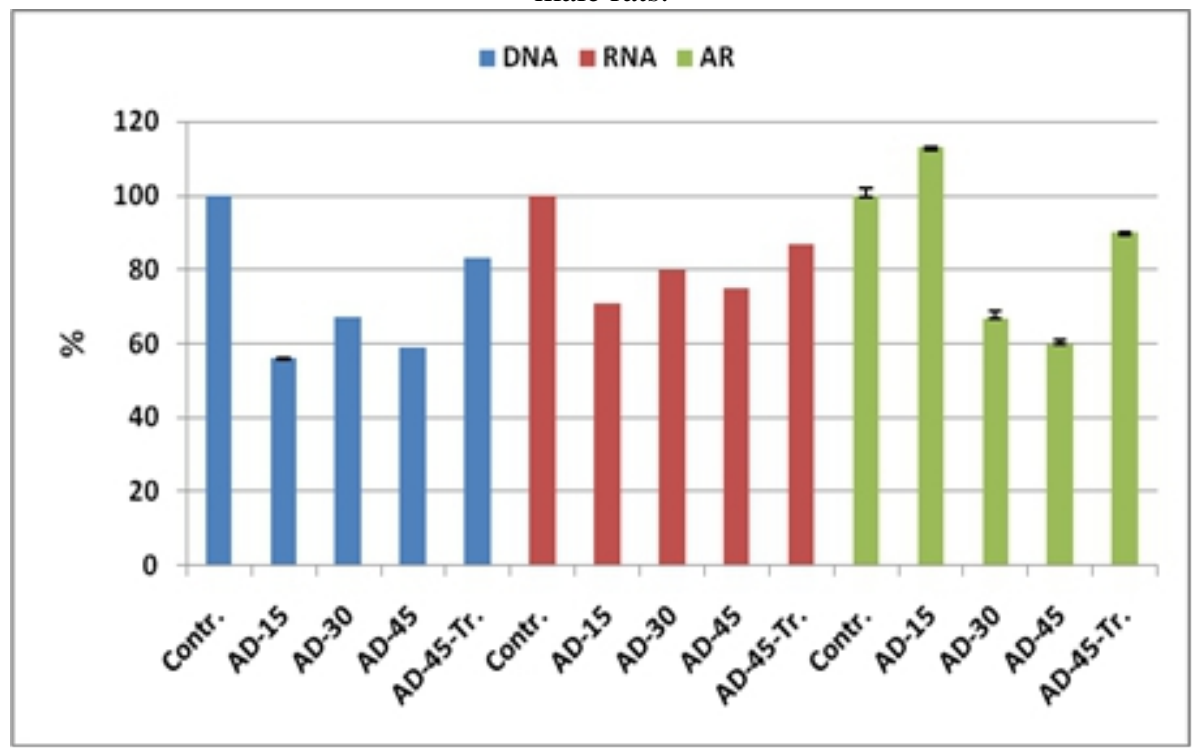

However, the administration of synthetic androgen during 15 days followed by increased $\mathrm{T}$ level in blood plasma lead to up-regulation and 
activation ("de-masking") of AR. Data showed that receptor binds to radioactive $\mathrm{H}^{3}$-methyltrienolone and cause further increase on the AR expression in liver tissue.

Despite the expression of liver AR after treatment with $\mathrm{H} 3$ methyltrinolone does not reach the control level, an increase in their number significantly supports the restoration of liver function, including adaptivecompensatory activities (Smirnov, 2009).

The increased glucose blood concentration during AD may be related to reduced glucose-related metabolism caused by enhanced corticosterone signaling. Under such circumstances, the increased level of steroid hormones stimulates gluconeogenesis from protein and amino acids metabolism (Imai, et al., 1993; Andrews \& Walker, 1999; Kinote, et al., 2012). The supplementation of $\mathrm{H}^{3}$-methyltrienolone reduced IRI resistance, hyperglycemia, corticosterone and $\mathrm{E}_{2}$ drastically altered during experimental diabetes in male rats.

\section{Conclusion}

The present study showed that AD alters IRI resistance and glucoserelated metabolism as well as the levels of both gonadal and adrenal steroids in blood plasma confirming the presence of "metabolic stress". The administration of exogenous androgen reduced the effect of "stress" and recovers the hormonal dysfunction induced by alloxan.

Restoration/functional activation of liver AR by methyltrienolone accompanied by increased DNA and RNA synthesis in hepatocytes plays the significant role in restoration of metabolic imbalance caused by AD.

\section{Conflict of interest}

No potential conflict of interest relevant to this submitted article is reported.

\section{Acknowledgments}

We thank Biomedical Research Network Center for Liver and Digestive Diseases (CIBERehd) founded by Instituto de Salud Carlos III and co-financed by European Development Regional Fund "A way to achieve Europe" ERDF and Al. Natishvili Institute of morphology, TSU - for their financial support.

\section{References:}

1. American Diabetes Association. (2009). Diagnosis and classification of diabetes mellitus. Diabetes care, 32 (Supplement 1), S62-S67.

2. Andrews, R. C., \& Walker, B. R. (1999). Glucocorticoids and insulin resistance: old hormones, new targets. Clinical Science, 96(5), 513- 
523.

3. Aregbesola AO, Voutilainen S, Virtanen JK, Mursu J, Tuomainen TP (2016) Gender difference in type 2 diabetes and the role of body iron stores. Ann Clin Biochem doi:10.1177/0004563216646397.

4. Didebulidze, N. A., Kakabadze, M. S., Gordadze, N. G., Latsabidze, I. N., Kordzaya, M. E., \& Sikharulidze, I. T. (2015). Correction of Hormonal and Metabolic Disorders in Male Rats with Developing Experimental Diabetes. Bulletin of experimental biology and medicine, 159(1), 20.

5. Fitzgerald, J. T., Anderson, R. M., \& Davis, W. K. (1995). Gender differences in diabetes attitudes and adherence. The diabetes educator, 21(6), 523-529.

6. Francés, D. E., Ronco, M. T., Monti, J. A., Ingaramo, P. I., Pisani, G. B., Parody, J. P., ... \& Carnovale, C. E. (2010). Hyperglycemia induces apoptosis in rat liver through the increase of hydroxyl radical: new insights into the insulin effect. Journal of Endocrinology, 205(2), 187-200.

7. Grant, J. F., Hicks, N., Taylor, A. W., Chittleborough, C. R., \& Phillips, P. J. (2009). Gender-specific epidemiology of diabetes: a representative cross-sectional study. International journal for equity in health, 8(1), 6 .

8. Greaves, S. C., Gamble, G. D., Collins, J. F., Whalley, G. A., \& Sharpe, D. N. (1994). Determinants of left ventricular hypertrophy and systolic dysfunction in chronic renal failure. American journal of kidney diseases, 24(5), 768-776.

9. Grossmann, M., Thomas, M. C., Panagiotopoulos, S., Sharpe, K., MacIsaac, R. J., Clarke, S., ... \& Jerums, G. (2008). Low testosterone levels are common and associated with insulin resistance in men with diabetes. The journal of clinical endocrinology \& metabolism, 93(5), 1834-1840.

10. Haffner, S. M., Katz, M. S., Stern, M. P., \& Dunn, J. F. (1988). The relationship of sex hormones to hyperinsulinemia and hyperglycemia. Metabolism, 37(7), 683-688.

11. Hayes, F. J., DeCruz, S., Seminara, S. B., Boepple, P. A., \& Crowley Jr, W. F. (2001). Differential regulation of gonadotropin secretion by testosterone in the human male: Absence of a negative feedback effect of testosterone on follicle-stimulating hormone secretion 1. The Journal of Clinical Endocrinology \& Metabolism, 86(1), 53-58.

12. Hayes, F. J., Seminara, S. B., DeCruz, S., Boepple, P. A., \& Crowley Jr, W. F. (2000). Aromatase Inhibition in the Human Male Reveals a Hypothalamic Site of Estrogen Feedback 1. The Journal of Clinical Endocrinology \& Metabolism, 85(9), 3027-3035. 
13. Holt, S. K., Lopushnyan, N., Hotaling, J., Sarma, A. V., Dunn, R. L., Cleary, P. A., ... \& Wessells, H. (2014). Prevalence of low testosterone and predisposing risk factors in men with type 1 diabetes mellitus: findings from the DCCT/EDIC. The Journal of Clinical Endocrinology \& Metabolism, 99(9), E1655-E1660.

14. Hotamisligil, G.S. (2006). Inflammation and metabolic disorders. Nature, 444 (7121), 860-867. doi:10.1038/nature05485.

15. Imai, E., Miner, J. N., Mitchell, J. A., Yamamoto, K. R., \& Granner, D. K. (1993). Glucocorticoid receptor-cAMP response elementbinding protein interaction and the response of the phosphoenolpyruvate carboxykinase gene to glucocorticoids. Journal of Biological Chemistry, 268(8), 5353-5356.

16. Kandeel, F. R., Swerdloff, R. S., \& Pryor, J. L. (Eds.). (2007). Male Reproductive Dysfunction: Pathophysiology and Treatment. CRC Press.

17. Kannel WB, Gordon T, Offutt D (1969) Left ventricular hypertrophy by electrocardiogram. Prevalence, incidence, and mortality in the Framingham study. Ann Intern Med; 71:89-105. doi:10.7326/00034819-71-1-89.

18. Kannel WB, Castelli WP, McNamara PM, McKee PA FM (1972) Role of blood pressure in the development of congestive heart failure. The Framingham study. $N$ Engl $J$ Med; 16:781-7. doi:10.1056/NEJM197210192871601

19. Kapoor, D., Goodwin, E., Channer, K. S., \& Jones, T. H. (2006). Testosterone replacement therapy improves insulin resistance, glycaemic control, visceral adiposity and hypercholesterolaemia in hypogonadal men with type 2 diabetes. European Journal of Endocrinology, 154(6), 899-906.

20. Kautzky-Willer, A., Harreiter, J., \& Pacini, G. (2016). Sex and gender differences in risk, pathophysiology and complications of type 2 diabetes mellitus. Endocrine reviews, 37(3), 278-316.

21. Kelly, D. M., \& Jones, T. H. (2013). Testosterone: a metabolic hormone in health and disease. Journal of Endocrinology, 217(3), R25-R45.

22. Kinote, A., Faria, J. A., Roman, E. A., Solon, C., Razolli, D. S., Ignacio-Souza, L. M., ... \& Lellis-Santos, C. (2012). Fructoseinduced hypothalamic AMPK activation stimulates hepatic PEPCK and gluconeogenesis due to increased corticosterone levels. Endocrinology, 153(8), 3633-3645.

23. Morimoto, S., Fernandez-Mejia, C., Romero-Navarro, G., MoralesPeza, N., \& DÍaz-Sánchez, V. (2001). Testosterone Effect on Insulin Content, Messenger Ribonucleic Acid Levels, Promoter Activity, and 
Secretion in the Rat 1. Endocrinology, 142(4), 1442-1447.

24. Moudgil, V. K. (1988). Steroid receptors in health and disease. In Steroid Receptors in Health and Disease (pp. 3-24). Springer US.

25. Moudgil, V.K., (1990) Phosphorylation of steroid hormone receptors. Biochim Biophys Acta - Mol Cell Res,1055(3), 243-58.

26. Orchard EJ, Dorman JS, Maser RE, Becker DJ, Drash AL, Ellis D, et al. (1990) Prevalence of complications in IDDM by sex and duration: Pittsburgh epidemiology of diabetes complications study II. Diabetes 39:1116-24. doi:10.2337/diabetes.39.9.1116.

27. Pitteloud, N., Mootha, V.K., Dwyer, A.A., Hardin, M., Lee, H., Eriksson, K.F., et al. (2005) Relationship between testosterone levels, insulin sensitivity, and mitochondrial function in men. Diabetes Care, 28(7), 1636-42.

28. Sato, K., Iemitsu, M., Aizawa, K., \& Ajisaka, R. (2008). Testosterone and DHEA activate the glucose metabolism-related signaling pathway in skeletal muscle. American Journal of PhysiologyEndocrinology and Metabolism, 294(5), E961-E968.

29. Shahidi, N. T. (2001). A review of the chemistry, biological action, and clinical applications of anabolic-androgenic steroids. Clinical therapeutics, 23(9), 1355-1390.

30. Shen, M., \& Shi, H. (2015). Sex hormones and their receptors regulate liver energy homeostasis. International journal of endocrinology, 2015.

31. Siddiqui, M. A., Khan, M. F., \& Carline, T. E. (2013). Gender differences in living with diabetes mellitus. Materia sociomedica, 25(2), 140.

32. Sinclair, M., Grossmann, M., Angus, P. W., Hoermann, R., Hey, P., Scodellaro, T., \& Gow, P. J. (2016). Low testosterone as a better predictor of mortality than sarcopenia in men with advanced liver disease. Journal of gastroenterology and hepatology, 31(3), 661-667.

33. Smirnov, A.N. (2009). Gormonalnie mechanizmi polovoi differentsirovki pecheni: sovremennie predstavleniya I problem Ontogenez, 40(5), 334-354. (Rus.).

34. Tepperman, J. (1968). Metabolic and endocrine physiology. An introductory text. Metabolic and endocrine physiology. An introductory text., (Edn 2). 